\title{
The governing of inclusion \\ Policy in Swedish school regulations and mathematics education
}

\section{Helena Roos}

In this study Swedish school regulations are investigated concerning inclusion and mathematics education. The texts are seen as socially produced written language. Discourse analysis is used focusing social interaction in the texts. The research question is, what in the regulation texts denotes and connotes inclusion, and how does this influence and govern inclusion in the case of mathematics education? Four Discourses were construed: the discourses of democracy and citizenship, of equity, of possibilities for participation and access, and of knowledge and assessment in mathematics. These Discourses make governing functions of inclusion visible. The functions are mostly ideological, and there appears to be a gap to how to actually do inclusion in the education. How this gap can be bridged needs to be considered by principals and teachers in their work for inclusion. Also, there are contradictions in the regulations. This implies that how in (ex)clusion in mathematics education is produced needs to be reconsidered by policy makers.

Keywords: discourse analysis, inclusion, mathematics education, school regulations.

\section{Introduction}

Although the concept of inclusion has been increasingly used over the last decade by both educational practice and educational research (e.g., Göransson, Nilholm \& Karlsson 2011; Isaksson \& Lindkvist 2015), it is not a concept used in the Swedish curriculum or Swedish School Act (SFS 2010:800). This can be seen as a bit odd because it has been used internationally since it was adapted by UNESCO

Helena Roos is associate senior lecturer at Malmö University and Linnaeus University, Sweden. E-post: helena.roos@mau.se 
in the 1994 Salamanca Declaration. The initial idea when adapting inclusion as a concept was to change the way we view special educational needs (SEN). In particular, rather than view SEN within the child, the aim was to view these needs within the organisation and the organisation's methods (Swedish UNESCO Council 2006). Inclusion is used in United Nations (UN) sustainable developmental goal number 4, quality education (United Nations n.d.), where it is stated that, by 2030, every person shall have equal access to all levels of education and the education is to be inclusive, giving every person the opportunity to participate. This implies participation from a democratic and humanitarian perspective on the levels of society, school and subject(s). In line with this, one way to define inclusion is processes of participation in society, school and subject(s), which is the definition used in this article. To exemplify processes of participation in a subject such as mathematics, opportunities are given to students to take part in the mathematics education and relate to peers and teachers in learning situations. At this level most often inclusion is used as a kind of tool. To show how the definition works on a societal level, the regulation texts give examples of various opportunities for participation in the (mathematics) education, such as being able to attend school. Here, ideological issues of inclusion are often visible. At the school level, the focus is on opportunities of participation at the school, for example, physical adjustments and/or the provision of special support. At this level, inclusion is used both as a kind of tool and as an ideology.

Mathematics is a subject where participation is often discussed both in school and in research (Roos, 2019a). This can be seen in, for instance, the notion of mathematics for all, which is used to signal the value of participation in mathematics for citizenship (Valero 2017). However, as Paola Valero (2017) points out, the notion of mathematics for all simultaneously "orders and ranks, and thus in(ex)cludes individuals and populations in relation to how much their mathematical achievement indicates their human capital” (p. 2). Consequently, this way of using participation can both include and exclude and involves (no) processes of participation on a societal level.

Given that inclusion can be seen as processes of participation, when studying Swedish school regulations, it is not unusual to find texts that connote inclusion. An example in the Swedish School Act (SFS 2010:800) is 9 \$ chapter 1, which states that all education shall be equal, and $10 \$$ chapter 1 , where it stipulates that all education shall take the child's best interest into consideration. Another example is in the curriculum (Lgr11) (The Swedish National Agency for Education 2019), where it is stated that the teacher "should take into account each individual's needs, circumstances, experiences" (p. 12). ${ }^{1}$ This 
shall be done by "organis[ing] and carry[ing] out the work so that students develop in accordance with their own capacity, and at the same time are stimulated into using and developing all their ability" (p. 13). Despite the presence of these segments of text, the direction of inclusion is not visible, given that inclusion as a concept is neither mentioned nor explained. This implies that in the Swedish school regulations - both in the general parts and in subject-specific content such as mathematics - the view of inclusion is cloaked. Here, mathematics education can be seen as a case of how the governing of inclusion sets the frame in the more general parts of the regulations. Therefore, the aim of this article is to investigate Swedish school regulation texts in relation to inclusion. Here mathematics education is used as a case to uncloak how governing documents in(ex)cludes students. The specific research question is, what in the Swedish school regulation texts denotes and connotes inclusion, and how does this influence and govern inclusion in the case of mathematics education?

\section{Background}

In Sweden, the value of inclusion has guided both the political agenda and the practical work in schools for decades (Isaksson \& Lindqvist 2015). Often, the notion of inclusion has been connected to special education rather than to a democratic education overall (Allan 2012). In a study of policy documents in the area of language learning for immigrants, it was found that the view of the notion of inclusion was instrumental and the students were positioned as in deficit (Fejes \& Dahlstedt 2017). This issue of who is in focus within the notion of inclusion and its connection to special education is also highlighted by Gunnlaugur Magnússon, Kerstin Göransson and Gunilla Lindqvist (2019). Upon examining from the wording in the 1994 Salamanca Declaration, they highlight the development of the notion of inclusion, with a focus on special education and deficits in its current form focusing on education for all. The conclusion is that inclusive education depends on the situation and context in both policy and culture (Magnússon, Göransson \& Lindqvist 2019).

Kerstin Göransson and Claes Nilholm (2014) identifies four different definitions of inclusive education in the research literature: the placing of special educational needs students in mainstream classrooms; the social academic needs of students in special educational needs; the social academic needs of every student; and the need to create communities. In the placement definition, inclusion as processes of participation is not visible, as it only focuses on the physical room. In 
the other three inclusion definitions, processes of participation can play a role depending on how they are used, although they are not foregrounded. However, in the definition focusing on creating communities, processes of participation may be a main issue given that communities involve people joining. Depending on the context and culture of the research, this implies that inclusion is interpreted and used differently, ranging from a strong connection to special education to that of a community issue. Here, depending on the context and culture, inclusion is used both as an ideology and as a tool.

When looking at special education and inclusion in Sweden, reforms regarding special education are more concerned with the individual perspective focusing on effects and performance; however, this leads to a contradiction within the interpretation of the notion of inclusion where individual performance is in focus on one hand and inclusive education on the other (Isaksson \& Lindqvist 2015). This contradiction also creates a tension in practice in relation to inclusive teaching (Hjörne 2016), leading to the question, should the students in special educational needs be included in the mainstream education or placed in special groups? In addition, if solely using individual performance as a measure of achievement, competition may result instead of a feeling of togetherness and the perpetuation of the notion that everyone can succeed. This is shown in a Swedish study by Julie Allan and Elisabeth Persson (2016; 2020), where, after an intervention focusing on inclusion, the students showed a normalization of diversity and a collective will to succeed. Also, social capital in the form of trust and confidence was found to be important for the students' sense of themselves as successful learners in inclusive education (Allan \& Persson 2020). Here, inclusion is used as a tool to achieve inclusion paired with certain ideological aspects.

When looking at the use of the notion of inclusion in the research paradigm of mathematics education, several definitions can be found. Most often, the words 'diversity' and 'equity' (e.g., Askew 2015) are used together with inclusion, indicating an ideological stance (Roos, 2019a). In addition, words like 'interventions' (e.g., Hart Barnett \& Shannon Cleary 2015) and 'inclusive classroom' (Moorehead \& Grillo 2014) are used, suggesting inclusion is a tool for teaching all students in the same classroom and indicating a placement definition of inclusion.

Although diversity and equity are notions used both in research and governing documents, they are abstract notions not easily understood nor easily put into practice (Roos, 2019a). One could argue that the use of these notions are attempts at instituting meanings, although complete control is not possible (Macedo, 2013). This lack of control makes these notions difficult to institutionally implement into 
the curriculum - in order to get teachers to move beyond their initial thoughts and put intentions into practice (Goodyear, Casey \& Kirk, 2017; Hargreaves \& Goodson 2006). Nevertheless, curriculum studies are trying to frame how governing texts, such as curriculums, can lead to sustainable educational change (e.g., Hargreaves \& Goodson, 2006).

\section{Theory}

In this study, the method of discourse analysis (DA) is used to investigate school regulation texts. The choice of DA was made because it opens up for the possibility to investigate text as a form of written language, which forms ways of saying, doing and being. Language has a certain function in a certain situation (Gee 2014a), therefore, by analysing the language and its use in specific texts, something can be understood about the social world. This implies that texts in Swedish school regulations that connote inclusion can be understood as a way of doing inclusion on a societal level.

At its core, DA has a social view on interactions between humans (Potter \& Wetherell, 1987). Here, according to Hugh Trappes-Lomax (2004), discourse can be seen as linguistic, cognitive and social processes where meanings are expressed. These processes are embedded historically and culturally as sets of conventions constituting and regulating the processes (Trappes-Lomax 2004). There are several different ways of both defining and using DA. In this article, discourse is defined as suggested by Trappes-Lomax (2004) and DA from the perspective of Gee $(2014 ; 2015)$ is used. The choice of DA from Gee's $(2014 ; 2015)$ perspective was made because of its focus on situations and contexts and because it foregrounds description.

As a result, this article aims to investigate school regulation texts in relation to inclusion where mathematics education is seen as a case. However, as in all DA, not only can descriptions of social interactions be made visible but also political and critical aspects, although they are in the background. Here, the second part of the aim of this article can be focused on, namely, to uncloak how governing documents in(ex)cludes students.

Gee (2014) distinguishes two theoretical notions, big and small discourses, hereafter referred to as Discourse with capital D (big) and discourse with lower case d (small). Discourse embodies a wider context, embracing both social and political values. A discourse (small) focuses on language in use in the conversations we investigate (Gee 2014), or more specifically, the relations between words and sentences and how these relations visualize themes within the conversations. 
The small discourses inform us of how language is used, how typical words and themes are made visible, and how language is designed by the writer. Discourse sets a larger context for the small discourse and is intimately related to the hieratical structure of society (Gee 2015).

DA can be seen as both a theory and a method and can be used as either or both at the same time (Gee 2014). This investigation of school regulation texts in relation to inclusion where mathematics education is seen as a case will be used as both a theory and an analytical tool, creating both a theoretical frame and a methodology focusing on social interaction in the form of text. The methodology is described in the next section.

\section{Methodology}

\section{Data}

This investigation of Swedish school regulation texts involves the analysis of the Swedish School Act (SFS 2010:800) and the Swedish national curriculum for the compulsory school, preschool class, and school-age educare, Lgr 11 (The Swedish National Agency for Education 2019). In the former, chapters 1 to 19 - and how the text therein applies to compulsory school and upper secondary school is investigated. In the latter, both the initial sections concerning the education in general and the sections concerning the mathematics curriculum are investigated. Mathematics education is interpreted as a case of inclusion where the more general parts of the Swedish school regulations are seen as framing parts. This implies that, although the mathematics curriculum has a small part in the texts analysed, it is seen as a case that is influenced by the more general parts. Hence, the mathematics curriculum is regarded as being embedded in, and in communication with, other more general parts of the curriculum due to the construction of the Swedish national curriculum for the compulsory school, preschool class, and school-age educare, Lgr 11. The translation from Swedish to English was made by the author in the case of the Swedish School Act (SFS 2010:800). In the case of the Swedish national curriculum for the compulsory school, preschool class and school-age educare, Lgr 11 (The Swedish National Agency for Education 2019), the English translation from National Agency for Education is used, with one exception: In the translation, the word 'pupil' is used, but in this study, the word 'student' is used for consistency. 


\section{Data analysis}

In this study discourse analysis (DA) is used as a method to investigate school regulation texts because it opens up for the possibility to investigate text as a form of written language forming ways of saying, doing and being. Gee (2014b) provides tools for this type of investigation, which highlights the communication by posing different questions to the text. These questions open up for investigation and exposes what is beyond the text in terms of $\mathrm{D}(\mathrm{d})$ iscourse. For example, the question, what sort of words are being used? can contribute to revealing the writer's intentions. Some tools are linguistic and stay close to the text and its context, while other tools give access to the interpretive level and are closer to what is happening on a societal level. Hence, the tools allow for the investigation of text on two different levels, but they at the same time correspond and thus show the connections between these two levels. This way of using the tools and questions helps me as a researcher to understand what in Swedish school regulations connotes with inclusion. It also allows me as a researcher to understand political and critical aspects and enables me to uncloak how governing documents in(ex)cludes students.

Gee (2014b) uses four categories to explain the workings of the tools: Language and context; Saying, doing and designing; Building things in the world; and Theoretical tools. In this investigation of Swedish school regulations, the focus is on what the texts are saying, doing and designing in terms of inclusion in mathematics education. Hence, the focus of the investigation will be on the tools within this category as well as the Theoretical tool, the Big "D" Discourse tool. The tools are described below and divided into linguistic tools and interpretative tools (Table 1). The format of the table sheds light on the correspondence between the linguistic and interpretative tools, where the linguistic tools are used to investigate the text in detail and the interpretative tools are used to interpret what is happening on an overarching level. The overall guiding question for the analysis when applying the tools were, what in the Swedish school regulation texts denotes and connotes inclusion, and how does this influence and govern inclusion in the case of mathematics education? Here, deliberately it was a wide scope when investigating the texts not to miss anything in the text connotating with inclusion. 
Table 1. List of linguistic, interpretative and theoretical tools used in the analysis.

\begin{tabular}{|l|l|}
\hline \multicolumn{2}{|c|}{ Saying, doing, and designing tools } \\
\hline Linguistic tools & Interpretative tools \\
\hline $\begin{array}{l}\text { The Vocabulary tool - } \\
\text { what sort of words are } \\
\text { being used, and how } \\
\text { does the distribution of } \\
\text { words function to mark } \\
\text { the communication in } \\
\text { terms of style? }\end{array}$ & $\begin{array}{l}\text { The Driter(s) trying to do? (can be several things). } \\
\text { the and not just saying tool - What is }\end{array}$ \\
\hline $\begin{array}{l}\text { The Stanza tool - How } \\
\text { do stanzas cluster into } \\
\text { larger blocks of infor- } \\
\text { mation? }\end{array}$ & $\begin{array}{l}\text { The Topic and theme tool - What is the topic } \\
\text { and theme for each clause? What theme is a set } \\
\text { of clauses? When the theme was not the topic } \\
\text { and deviated from the usual choice, why was } \\
\text { it chosen? }\end{array}$ \\
\hline $\begin{array}{l}\text { Theoretical tool } \\
\text { this way and not in some other way? }\end{array}$ \\
\hline
\end{tabular}

When applying the theoretical notions of discourse and Discourse in the analysis, firstly, relations between words and sentences were investigated (discourses). This investigation was made by using the Vocabulary tool and the Stanza tool on the linguistic level. Then, the Doing and not just saying tool, the Why this way and not that way? tool, and the Topic and theme tool were used on an interpretative level. This helped to visualize themes within the conversations, and discourses were construed. Thereafter, the Big " $\mathrm{D}$ " discourse tool (Gee 2014b) (see questions above) was applied, and Discourses that set the larger social and political context were construed. Here, the relationship between discourse and Discourse were seen in how the Discourse sets the larger social and political context in terms of what sort of actions, interactions, values and beliefs were associated with the sort of language used in the discourses. Although this may seem like a linear process, the analysis and construction of discourses and 
Discourses was more of a circular back-and-forth analytical process. This process made visible the $\mathrm{D}(\mathrm{d})$ iscourses that frame and constrain the governing of inclusion where mathematics education is a case in Swedish school regulations.

\section{Discourses of inclusion in Swedish school regulations}

In the analysis of the Swedish school regulations text, four Discourses were construed: the Discourse of democracy and citizenship; the Discourse of equity; the Discourse of possibilities for participation and access; and the Discourse of knowledge and assessment in mathematics. These Discourses describe inclusion and what governs inclusion from a regulating level. Here, mathematics education is seen as a case, framed by the general parts in the Swedish school regulations. Below, the four Discourses are presented under each respective heading.

\section{Discourse of democracy and citizenship}

The small discourses humanity and human rights, participation in society, and right to education together comprise a Discourse of democracy and citizenship. The following section gives an explanation of how they are construed.

A (small) discourse of humanity and human rights is construed because both the curriculum (Lgr11) and the Swedish School Act (SFS 2010:800) highlight humanity and human rights. In 4 \ chapter 1, the Swedish School Act (SFS 2010:800) states that the education shall "convey and anchor respect for human rights and fundamental democratic values on which the Swedish society rests". The Act also highlights that each and every person working in education should promote human rights. This echoes into the curriculum (Lgr11) with the statement that "the school should promote understanding of other people and the ability to empathise" (The Swedish National Agency for Education 2019, p. 5). When mentioning the words 'human rights', democracy is mentioned in the same breath, both in the Swedish School Act (SFS 2010:800) and the curriculum (Lgr11).

In relation to democracy, a discourse highlighting participation in society was construed. The Swedish School Act (SFS 2010:800) stipulates that "the education shall be formed to prepare students for active life choices and a basis for further education". In addition, 


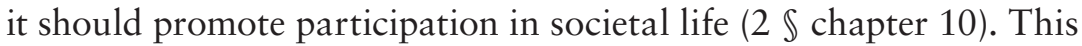
is also highlighted in the curriculum (Lgr11), which states that "the task of the school is to encourage all students to discover their own uniqueness as individuals and thereby be able to participate in the life of society by giving of their best in responsible freedom" (The Swedish National Agency for Education 2019 p. 5). Also the curriculum (Lgr11) highlights its mission to foster democratic citizens by stating democratic working forms should also be applied in practice and prepare students for active participation in the life of society". (The Swedish National Agency for Education 2019 p. 7). The curriculum goes even further, where an aim for school is to promote "knowledge of democratic principles and develop the ability to work in democratic forms" (The Swedish National Agency for Education 2019, p. 13). Even in mathematics subject-specific parts of the curriculum (Lgr11), the importance of taking part in society is highlighted: "Knowledge of mathematics gives people the pre-circumstances to make informed decisions in the many choices faced in everyday life and increases opportunities to participate in decision-making processes in society" (p. 55).

Another small discourse in the big Discourse of democracy and citizenship is right to education. According to the Swedish School Act (SFS 2010:800) 8 \ chapter 1, "everyone, regardless of geographical residence and social and economic circumstances, shall have equal access to education in the school system". Also, the heading of chapter 7 contains the wording, the "right to education", and it is stated in 3 $\$$ chapter 7 that "all children who are subject to public school duty have the right to free education in public school". This echoes into the curriculum (Lgr11), where it is stated that the school should make the goals of the education clear and the rights and obligations of the students and guardians clear (p. 6). One way the curriculum (Lgr11) operationalizes the right to education is in the promotion of student participation in school development. This is especially highlighted in the section, Responsibility and influence of students, where it is stated that "the democratic principles of being able to influence, take responsibility and be involved should cover all students. Students should always have the opportunity to take the initiative on issues that should be treated within the framework of their influence over their education" (The Swedish National Agency for Education 2019, p. 13). The curriculum (Lgr11) also states that there shall be a cooperation between the school, the home and the society in order to foster democracy and citizenship. 


\section{Discourse of equity}

The small discourses of equal access, adaption of the education, and all students - every student together comprise a Discourse of equity. How they are construed is shown below.

A (small) discourse about equal access to education is construed. For example, the Swedish School Act (SFS 2010:800) states that "everyone should, regardless of geographical location and social and economic circumstances, have equal access to education" $(8 \mathbb{\$}$ chapter 10). Also, it stipulates that education in the school system shall be equal regardless of where in the country it is organized $(9 \mathbb{S}$ chapter 10). Equal access to education and equal education are highlighted in the Swedish School Act (SFS 2010:800) with headings that indicate that this is important to reconsider in the education. Also, the Swedish School Act (SFS 2010:800) highlights that the best interests of the child are to be taken into consideration, indicating the importance of reconsider what is best for the individual student. This echoes into the curriculum in the statement that "Teaching should be adapted to each student's circumstances and needs." (The Swedish National Agency for Education 2019, p. 6). In relation to this, the curriculum (Lgr11) points out that equal does not imply the same education to everyone: "Equivalent education does not mean that the education should be the same everywhere or that the resources of the school are to be allocated equally. Account should be taken of the varying circumstances and needs of students" and "education can never be the same for all." (The Swedish National Agency for Education 2019, p. 6).

In relation to equal access, a discourse of adaption of the education was construed. Here, the Swedish School Act (SFS 2010:800) stipulates that "all children and students in all school forms and in the school-age educare should be given the guidance and stimulation they need in their learning and personal development in order to develop as far as possible according to the educational goals and in relation to their circumstances" ( $2 \mathbb{S}$ chapter 3$)$. Also, a heading in the Swedish School Act (SFS 2010:800), "Support in the form of extra adaptations" $(5 \mathbb{S}$ chapter 3$)$, implies that adaption for students in need to be able to reach the curriculum goals is important. In addition, the Swedish School Act (SFS 2010:800) stipulates a guarantee for early extra adaptions and special support in Mathematics, Swedish, and Swedish as a Second Language (4 $\mathbb{S}$ chapter 3$)$. In the curriculum (Lgr11) this is specified to concern students in need of special support in preschool class and lower primary school in order to reach the curriculum goals (p. 11). However, it also states that "teaching should be adapted to 
every students' circumstances and needs" (The Swedish National Agency for Education 2019, p. 6).

Another small discourse within this big Discourse of equity is all students - every student. The investigated parts of the Swedish School Act (SFS 2010:800) use the words 'all students' 13 times in relation to access in the education for all students, in relation to activities connected to the school, and in relation to free education (economically). In the investigated parts of the curriculum (Lgr11), the words 'all students' are used eight times. Here, these words are used in relation to the following aspects: the development of learning for all, the school environment, the encouragement of all students to discover their own uniqueness, the development of their own ability, and being given the opportunity to learn.

The investigated parts of the Swedish School Act (SFS 2010:800) use the words 'every student' 30 times, most often in relation to what shall be offered from the school to every student. The words are in relation to being offered health care, economic support from the home municipality if going to school in another municipality, choice of language to learn, education time offered, adaptions to every students' circumstances, mentors, apprenticeships and individual study plans. In contrast, in the investigated parts of the curriculum (Lgr11), the words 'every student' is used 12 times. Here, the words are in relation to adaption of the education according to circumstances and needs, opportunities to develop communication skills, the stimulation of selfdevelopment and personal growth, the right to develop in school, the stimulation of norms and values of the Swedish society and towards the educational goals as such. Hence, both the Swedish School Act (SFS 2010:800) and the curriculum (Lgr11) highlight the importance of taking into consideration the needs of every student in education.

\section{Discourse of possibilities for participation and access}

The small discourses development and learning, togetherness, security and learning, special education and opportunities and circumstances together comprise a Discourse of possibilities for participation and access. How they are construed is explained below.

A (small) discourse of development and learning is construed given that it is highlighted both in the curriculum and the Swedish School Act (SFS 2010:800). This is seen in how both of the texts use the words development and learning several times. In the Swedish School Act (SFS 2010:800), it is in relation to what education as such should do, and in the curriculum, it is both that education should 
stimulate development and learning as well as the school and the teachers. For example, the Swedish School Act (SFS 2010:800) (4 $\mathbb{S}$ chapter 1) stipulates that "the education within the school system aims to ensure that children and students acquire and develop knowledge and values. It will promote the development and learning of all children and students, as well as a lifelong desire to learn'. This is referenced to in the curriculum (Lgr11), where it is stated that the education should promote 'the development and learning of all students, a lifelong desire to learn' (The Swedish National Agency for Education 2019, p. 5).

Within this Discourse, a discourse of Togetherness, security and learning is construed. In relation to the aim of the education in upper secondary school, the Swedish School Act (SFS 2010:800) states that the "education should be designed promoting social togetherness and development of students' ability to independently and together with others acquire, deepen and apply knowledge" (2 $\int$ chapter 15$)$. Interestingly, this is not mentioned in relation to compulsory school in the Swedish School Act (SFS 2010:800). Though, it is visible in the curriculum (Lgr11) where it is stated that the students 'should have the opportunity to take initiatives and assume responsibility, and to develop their ability to work both independently and together with others' (The Swedish National Agency for Education 2019, p. 8). Also, it is written in the curriculum (Lgr11) that the school should give the students "the opportunity to develop good peer relationships and to feel a sense of belonging and security" (The Swedish National Agency for Education 2019, p. 23). Security is also highlighted several times in the Swedish School Act (SFS 2010:800), and here, it is always together with the Swedish word, studiero, which means a calm study environment (e.g., SFS 2010:800 chapter 5). This implies that the school is required to secure the students environment for learning.

Another discourse construed within this Discourse of possibilities for participation and access is special education. In order to get participation and access to the mathematics, the strategy of early intervention is highlighted both in the Swedish School Act (SFS 2010:800) and the curriculum (Lgr11). Here, the aforementioned guarantee for early interventions stipulated in the Swedish School Act (SFS 2010:800) makes this even more visible. To be able to keep the guarantee, extra adaptions and special support is called upon in the Swedish School Act (SFS 2010:800). It is also stipulated that the school organization is responsible to hold special competence to consult when carrying out the special support (4 a $\mathbb{S}$ chapter 3 ). In the curriculum (Lgr11) this is highlighted by stipulating that the "teachers should stimulate, guide and offer extra adaptions or special support" and also "cooperate 
with other teachers to attain the goals of the education" (The Swedish National Agency for Education 2019, p. 13).

In line with the text about special support, a discourse of opportunities and circumstances is construed. In several places in the Swedish School Act (SFS 2010:800) (e.g., 12 \$ chapter 10) it is stipulated that the student and the guardians shall be informed of the efforts needed for the student to get the opportunity to reach the knowledge requirements and develop as far as possible within the framework of the curriculum. Also, in relation to the school form of special school, it is written that the education shall be adapted to the circumstances of every student $(2 \mathbb{S}$ chapter 12$)$. In the curriculum (Lgr11) students' circumstances are mentioned several times in relation to both giving the right circumstances for learning and also in relation to taking students' circumstances into consideration in order to provide possibilities for learning and access. Also, according to the curriculum (Lgr11), the students "should have the opportunity to take initiatives and assume responsibility (The Swedish National Agency for Education 2019, p. 8).

\section{Discourse of knowledge and assessment in mathematics}

The small discourses of mapping knowledge, knowledge requirements and communicating knowledge, support to create opportunities and circumstances together comprise a Discourse of knowledge and assessment in mathematics. The following section shows how they are construed.

A (small) discourse of mapping knowledge is construed. Here, the Swedish School Act (SFS 2010:800) stipulates that in order to make an evaluation of students' knowledge development, a national evaluation material shall be used in preschool class, and in lower primary school a national evaluation material or a national test $(4 \mathbb{S}$ chapter $3)$. In $5 \mathbb{S}$ chapter 3 , it is stipulated that if the result on a national test or tasks from the teacher lead to the concern "that a student will not reach the knowledge requirements [...] the student should promptly be supported in the form of extra adaptions within the regular teaching situation". This is not explicitly mentioned in the curriculum (Lgr11). Instead, the specific knowledge requirements are referred to when talking about supporting the awarding of grades, but it also mentions taking "all available information about the students' knowledge and learning” (The Swedish National Agency for Education 2019, p. 17) into consideration. 
In relation to mapping knowledge, a small discourse of knowledge requirements and communicating knowledge is construed. Both the Swedish School Act (SFS 2010:800) and the curriculum (Lgr11) highlight knowledge requirements and communicating knowledge by grades and the evaluations of knowledge. ${ }^{2}$ For example, in the Swedish School Act (SFS 2010:800), it is stated that the teacher shall "provide evaluations of the students' knowledge development in relation to the knowledge requirements" (13 \$ chapter 10). In the curriculum (Lgr11) it is stated that "the teacher should through development dialogues and personal development plans further the students' knowledge and social development" (The Swedish National Agency for Education 2019, p. 16). Also, it is stated that the teacher should, "when awarding grades, make use of all available information about the student's knowledge and learning in relation to the national knowledge requirements, and make an all-round assessment of this knowledge" (The Swedish National Agency for Education 2019, p. 17). When it comes to the headteacher, the curriculum (Lgr 11) stipulates that the headteacher is responsible for ensuring the "allocation of resources and remedial measures are related to teachers' assessments of the students' development" (The Swedish National Agency for Education 2019, p. 17).

Connected to the mission of the teacher, in both the Swedish School Act (SFS 2010:800) and the curriculum, one can see how the support and interventions of the teacher(s) shall provide the students with opportunities and circumstances to develop mathematical knowledge. Hence, a discourse of support to create opportunities and circumstances is construed. ${ }^{3}$ Here, the Swedish School Act (SFS 2010:800) emphasizes the importance of having educated teachers to conduct the teaching by stating that "only those who have a certificate as a teacher or a preschool teacher and who are qualified for a particular teaching may conduct the teaching" (13 $\$$ chapter 2$)$. The Swedish School Act (SFS 2010:800) also stipulates that "support shall be given aiming at counteracting the consequences of a disability as much as possible" ( $2 \mathbb{S}$ chapter 3$)$, implying that the school has a mission to create opportunities to learn. In the curriculum (Lgr11), students' opportunities to understand and opportunities to develop their ability in relation to different parts in mathematics is referred to (p. 56). Also, it is stated that "teaching in mathematics should aim at helping the students to develop knowledge of mathematics and its use in everyday life and in different subject areas" (The Swedish National Agency for Education 2019 p. 55). In the mathematics curriculum in Lgr11, the word 'opportunity/opportunities' is mentioned six times, and the word 'circumstances' is mentioned five times, indicating 
a focus in the curriculum on building a supporting education by creating opportunities and circumstances for all students to participate in the education.

\section{Discussion}

Given that the word 'inclusion' is neither used explicitly in the Swedish School Act (SFS 2010:800) nor in the curriculum (Lgr11), the view of inclusion in the regulations is somewhat cloaked and thus can be interpreted as invisible. However, following the result of this study, we can conclude that there are governing functions of inclusion in Swedish school regulations, and these regulations indicate influence on the in(ex)clusion of students in mathematics education.

This in(ex)clusion can be seen in the Discourse of Democracy and citizenship, where it is highlighted how Swedish school regulations aim at including every student, as a way for them to not only be a part of society and be treated in a humanitarian way but also be taught how to act and think in a humanitarian way. One might say that this is a community definition of inclusion, if using the four different types of definitions identified by Göransson and Nilholm (2014). Unlike Fejes and Dahlstedt's (2017) study, in this Discourse, inclusion is neither instrumental, nor does it position the students as in deficit. Instead, the focus lies in the processes of participation of every student both to be treated and act in a democratic way. Hence, in this Discourse, there is certainly a call for the inclusion of students in the governing documents.

Within the Discourse of equity, in(ex)clusion can be seen in how the Swedish school regulations promote equity and the importance of taking every student into consideration. However, this is somewhat contradictory when looking at the texts about the guarantee for early extra adaptions and special support. Here, reaching the curriculum goals is in focus, and the extra adaptions can be interpreted as solely applying to the students who do not reach the curriculum goals; like the finding in Fejes and Dahlstedt's (2017) study, this positions the students as in deficit. Hence, there are wordings in the Swedish school regulations that indicate exclusion. Nevertheless, it is also stated that "teaching should be adapted to every students' circumstances and needs" (The Swedish National Agency for Education 2019, p. 6), which positions students as competent and implies that even if students reach the goals, they may need extra adaptations in order to optimize learning. This is also what Roos (2019b) concluded when discussing the needs of students in special educational needs in 
mathematics (SEM) - more specifically, that even if a student has access to the mathematics presented in the classroom, they might need some extra adaption as a way to optimize learning. Hence, if opting to interpret inclusion as processes of participation, the implication for school is to take all students into consideration regarding extra adaptions in order to optimize learning and not exclude. Moreover, when looking at the words 'all students' contra the words 'every student', 'all students' shows potential contradictions regarding who is seen, heard and supported because the notion of students already implies all students and begs the question of why all as a prefix should even be needed. This has been debated in research regarding inclusion (e.g., Popkewitz, 2004), and the term 'every student' has been suggested to be used instead, to depart from the opportunities of every student (Roos, 2019b). Interestingly, both 'all' and 'every student' were used in the Swedish school regulations but used rather randomly and perhaps not reflected upon. Nevertheless, the use of 'all' and 'every' signals a form of in(ex)clusion in relation to achievement. As Valero (2017) states, this indicates the student's human capital. Being careful not to perpetuate human capital in the form of achievement and thus increasing the exclusion of the individual student is important to reflect on when using these regulations.

Within the Discourse of Possibilities for participation and access, in(ex)clusion can be seen in how the Swedish school regulations aim at creating spaces for participation and access in the education. Here, creating a feeling of security and learning together with others is highlighted, which can be related to the social capital of trust and confidence that students found important for inclusion by Allan and Persson (2020). However, in this Discourse, special education was highlighted as a form of security for access to the education. This could be seen as contradictory to learning together and creating a sense of security, depending on how the special education is performed at the local school. Therefore, how the special education is viewed, planned and performed becomes critical for inclusion. Emerging from this is a call for more attention to be directed at not excluding when aiming for the inclusion of the individual student in special education.

Within the Discourse of Knowledge and assessment in mathematics, in(ex)clusion can be seen in how a strong assessment discourse greatly limits inclusion and perhaps even creates exclusion for students. In this Discourse, we see how mapping knowledge and knowledge requirements can cloak the other discourses within this Discourse if a teacher or a principal does not follow both the Swedish School Act (SFS 2010:800) and the entire curriculum (Lgr11) (not only knowledge requirements). Therefore, this Discourse can be dangerous and thus 
threatens inclusion in mathematics education, possibly even creating exclusion for students. However, if the teacher and/or principal uses the entire curriculum (Lgr11) in relation to the knowledge requirements, then this can enhance inclusion in mathematics education. Consequently, assessment, and how it is looked upon, certainty has a gatekeeping function for inclusion in mathematics education from a regulating level. This falls in line with research findings from classroom studies (Bagger, 2017; Björklund Boistrup, 2016), exposing how the assessment discourse perpetuates all levels of teaching (and learning) in mathematics. This becomes even more enhanced by the stipulation in the law that schools shall use governmental evaluation materials and national tests to determine who is entitled to receive extra adaptions and special support. Hence, there is a call for more attention to be directed at not producing exclusion when aiming at including the individual student in the work with assessments in schools.

The $\mathrm{D}(\mathrm{d})$ iscourses construed and described in this article should not be regarded as static and distinct from each other but rather seen as showing in the small discourses how they relate and depend on each other. Furthermore, they can be seen somewhat differently depending on the interpretation and from which perspective the regulations are viewed, and as a result, different Discourses can be more or less visible. This means that the interpretation and operationalization of the Swedish school regulation texts greatly influence how in(ex)clusion is produced at the local school level, and ultimately, this affects the individual students learning in mathematics.

Relating this investigation of inclusion in Swedish school regulations to a study made of inclusion in mathematics in research (Roos, 2019a), it can be seen that - with words like 'democracy', 'citizenship' and 'equity' - the Discourses in this investigation have a strong tendency towards inclusion as an ideology. A few of the small discourses, for instance, the discourse support to create opportunities and circumstances and the discourse of special education have a vague direction towards inclusion as a tool, although it is not made explicitly clear how to do inclusion. Therefore, there seems to be a distinctive gap between Swedish school regulations and how to actually do inclusion in the education. Also, given that there are contradictions in the regulations, succeeding in doing inclusion depends on how the local school and the teachers to interpret what they should do. This is evidence that if and how inclusion is implemented depends on how the local school, the principal and the individual teacher interpret and operationalize the Swedish school regulations. Only when the ideological writings are used as a tool in school can one tell how inclusion in mathematics education can be visible and 
made real. This implies that much of the responsibility for inclusion lies in the hands of the local school and the teacher. Therefore, the risk is that sustainable educational change regarding inclusion will not happen. This is also because the Swedish school regulations do not use the word 'inclusion' at all, neither do they reflect on inclusion from the initial aim to change the way we view special educational needs (SEN) from an individual deficit perspective to an organisational perspective focusing on educational methods. This implies that when striving to achieve sustainable educational change regarding inclusion in mathematics education in the Swedish governing school regulations, how SEN is viewed and how in (ex)clusion is produced by the regulations needs to be reconsidered by the policy makers in the regulating texts. Also, principals and teachers need to consider how the gap between the local autonomy of schools and the regulations can be bridged as they work for inclusion, and consequently, not create exclusion when aiming for the inclusion of every student in mathematics teaching and learning.

Notes

1. The word 'circumstance' is used by the Swedish National Agency for Education (2019). In this article it implies both individual and social issues surrounding the student - in Swedish, the terms förutsättningar och villkor are used.

2. In Swedish, betyg och omdömen.

3. In Swedish, möjligheter och förutsättningar.

\section{References}

Allan, Julie (2012): The inclusion challenge. In Thomas Barow \& Daniel Östlund, eds.: Bildning för alla! En pedagogisk utmaning [Education for all! A pedagogical challenge], pp. 109-120. Kristianstad: Högskolan i Kristianstad.

Allan, Julie \& Persson, Elisabeth (2020): Social capital and trust for inclusion in school and society. Education, Citizenship and Social Justice, 15(2), 151-161. 
Allan, Julie \& Persson, Elisabeth (2016): Students' perspectives on raising achievement through inclusion in Essunga, Sweden, Educational Review, 68(1), 82-95.

Askew, Mike (2015): Diversity, inclusion and equity in mathematics classrooms: From individual problems to collective possibility. In Alan Bishop; Hazel Tan \& Tasos N. Barkatsas, eds.: Diversity in Mathematics Education: Towards Inclusive Practices, pp. 129-145. Cham: Springer International Publishing.

Bagger, Anette (2017): Den flerspråkiga elevens nationella provdeltagande i matematik: Diskursiva förutsättningar [Multilingual students' participation in national tests in mathematics - discursive prerequisites]. Utbildning \& Demokrati - tidskrift för didaktik och utbildningspolitik, 26(2), 95-111.

Björklund Boistrup, Lisa (2016): Assessment in mathematics education: A gatekeeping dispositive. In Nina Bohlmann, Alexandre Pais \& Hauke Straehler-Pohl, eds.: The Disorder of Mathematics Education, pp. 209-230. Dordrecht, the Netherlands: Springer.

Fejes, Andreas \& Dahlstedt, Magnus (2017): Popular education, migration and discourse of inclusion. Studies in the Education of Adults 49(2), 214-227.

Gee, James Paul (2014a): An Introduction to Discourse Analysis: Theory and Method. New York: Routledge.

Gee, James Paul (2014b): How to do Discourse Analysis: A Toolkit. London: Routledge.

Gee, James Paul (2015): Discourse, small-d, big D. In Karen Tracy, Cornelia Ilie and Todd Sandel, eds.: The International Encyclopedia of Language and Social Interaction, 3, pp. 1-5. John Wiley \& Sons.

Goodyear, Victoria A.; Casey, Ashley, \& Kirk, David (2017): Practice architectures and sustainable curriculum renewal, Journal of Curriculum Studies, 49(2), 235-254.

Göransson, Kerstin \& Nilholm, Claes (2014): Conceptual diversities and empirical shortcomings - A critical analysis of research on inclusive education. European Journal of Special Needs Education, 29(3), 265-280.

Göransson, Kerstin; Nilholm, Claes \& Karlsson, Kristina (2011): Inclusive education in Sweden? A critical analysis, International Journal of Inclusive Education, 15(5), 541-555.

Hargreaves, Andy \& Goodson, Ivor (2006): Educational change over time? The sustainability and nonsustainability of three decades of secondary school change and continuity. Educational Administration Quarterly, 42(1), 3-41. 
Hart Barnett, Julie E. \& Cleary, Shannon (2015): Review of evidence-based mathematics interventions for students with autism spectrum disorder. Education and Training in Autism and Developmental Disabilities, 50(2), 172-185.

Hjörne, Eva (2016): The narrative of special education in Sweden: History and trends in policy and practice. Discourse - Studies in the Cultural Politics of Education, 37(4), 540-552.

Isaksson, Joakim \& Lindqvist, Rafael (2015): What is the meaning of special education? Problem representations in Swedish policy documents: late 1970s-2014, European Journal of Special Needs Education, 30(1), 122-137.

Macedo, Elizabeth (2013): Equity and difference in centralized policy: Journal of Curriculum Studies, 45(1), 28-38.

Magnússon, Gunnlaugur; Göransson, Kerstin, \& Lindqvist, Gunilla (2019): Contextualizing inclusive education in educational policy: The case of Sweden. Nordic Journal of Studies in Educational Policy, 5(2), 67-77.

Moorehead, Tanya \& Grillo, Kelly (2014): Celebrating the reality of inclusive STEM Education co-teaching in science and mathematics. Teaching Exceptional Children, 45(4), 50-57.

Popkewitz, Thomas S. (2004): The alchemy of the mathematics curriculum: Inscriptions and the fabrication of the child. American Educational Research Journal, 41(1), 3-34.

Potter, Jonathan \& Wetherell, Margret (1987): Discourse and Social Psychology: Beyond Attitudes and Behavior. London: Sage.

Roos, Helena (2019a): Inclusion in mathematics education: An ideology, a way of teaching, or both? Educational Studies in Mathematics Education, 100(1), 25-41.

Roos, Helena (2019b): The Meaning of Inclusion in Student Talk: Inclusion as a Topic When Students Talk about Learning and Teaching in Mathematics. Ph. D. Thesis. Linnaeus University: Växjö.

Swedish UNESCO council (2006): Salamancadeclaration and Salamanca +10. Stockholm.

SFS 2010:800. Skollag [The Swedish School Act]. Stockholm: Utbildningsdepartementet.

The Swedish National Agency for Education (2019): Curriculum for the Compulsory School, Preschool Class and School-Age Educare. Revised 2019. Stockholm: The Swedish National Agency for Education.

Trappes- Lomax, Hugh (2004): Discourse Analysis. In Alan Davies, \& Cathrine Elder, eds.: The Handbook of Applied Linguistics, pp. 133-164. Malden, Mass.: Blackwell Publishing. 
United Nations (n.d.): Sustainable developmental goals. Retrieved from https://www.un.org/sustainabledevelopment/education/

Valero, Paola. (2017): Mathematics for all, economic growth, and the making of the citizen-worker. In Thomas S. Popkewitz, Jennie Diaz \& Christopher Kirchgasler, eds.: A Political Sociology of Educational Knowledge: Studies of Exclusions and Difference, pp. 117-132. New York: Routledge. 